\title{
The Parker Gold Piece
}

\author{
EVIDENCE OF IN SITU GOLD CRYSTALLISATION?
}

\author{
Mary D. Albanese \\ Alaska Division of Geological and Geographical Surveys
}

\begin{abstract}
It bas been documented that gold crystals can nucleate on common micron-sized bacterial spores that bave come into contact with aqueous gold (Watterson et. al, 1984). This researcb raises the controversial question 'Can Gold crystals grow in situ by naturally occurring chemical processes?'
\end{abstract}

In 1959, a mining engineer, Mr. Karl Parker, found a oneounce 1908 U.S. gold coin (Twenty Dollar Statue) in a sluice box during the cleanup of his placer mining operation on Eva Creek near Fairbanks, Alaska. This gold coin, now in the possession of his widow Mrs. Gladys Parker Blood, contains a number of subrounded and possibly faceted gold particles up to a millimeter in length which are firmly attached to the coin. These particles may represent gold crystals which have nucleated in place upon the coin or may simply be microfine nuggets which have adhered to the coin prior to or during the sluicing process. I learned of the coin during a co-operative investigation between the United States Geological Survey (USGS) and the Alaska Division of Geological and Geophysical Surveys (ADGGS). In 1982, the USGS, under the direction of John Cathrall and Jack Antweiller, began a massive effort to sample and characterise gold throughout Alaska. The purpose of the project is to uncover clues leading to the precise details of the formation of Alaska's placer deposits and to target new locations for placer or lode gold exploration. By 1984 they had talked to numerous miners and had collected and analysed over 500 samples. Geologists in my organisation, the ADGGS, were invited to participate in the project and several of us did so. We had all heard about the unusual Parker gold coin but none of the USGS or AGDDS geologists had actually seen it until last summer, when I was informed that Mrs. Gladys Parker Blood would be visiting Fairbanks. We contacted her and she graciously allowed us the opportunity to photograph the coin.

If these gold particles on the Parker Gold Piece are indeed the result of naturally occurring gold nucleation, important implications concerning the formation of placer gold would be apparent. In particular, although gold is generally considered an insoluble element whose concentration in placer deposits is controlled by stream dynamics independent of environmental and geochemical parameters, it has recently been suggested that gold may become soluble under certain physical, chemical and electrical conditions unique to regions of cold climate.
This gold in solution could then be transported and redeposited (2). Watterson explains how this process might occur by stating:

\begin{abstract}
'Several effects which may influence the weathering of natural goldbearing rocks, the chemical complexation of gold, and its subse quent mobility and deposition appear to be strongly connected with freeze action. The exclusion of dissolved solutes, solute gases, and particles from ice, subjects rock and soil minerals to increased corrosion from thin, unfrozen, adsorbed water films which remain at particle surfaces throughout the freezing of rocks and soils. The preferential exclusion of cations (over anions) from growing ice crystals creates charge separations and measurable flow across water-ice phase boundaries in freezing soil - a phenomenon which leads to troublesome seasonal electrolytic corrosion of pipelines buried in soil; this phenomenon may also favour the dissolution of normally insolvable metals such as gold during geologic time periods. The ice-induced accumulation of clays, organic acids, bacteria, and other organic matter at mineral surfaces may also speed chemical attack by providing a nearby sink of alternate cation-binding sites and hence rapid removal of literated cations from solution. The latter mechanism may be operative in both the dissolution and redeposition of gold' (2).
\end{abstract}

At this time, the exact origin of the gold particles adhering to the Parker Gold Piece is uncertain. No destructive tests can be considered, and the coin is ordinarily stored far from research facilities which makes arrangements for further investigation difficult. In any event, the coin represents an intriguing artefact not only for the controversial issues concerning gold deposition that it stimulates, but because of its unusual history and circumstances of discovery.

\section{References}

1 J.R. Watterson, J.M. Nishi and T. Botinelly, 'Evidence that Gold Crystals can Nucleate on Bacterial Spores', in S. Bartsch-Winkler and K. Reed, Editors, The United States Geological Survey in Alaska; Accomplishments During 1983, United States Survey Circular 945, 1984, 1-4

$2 \mathrm{~J}$. Watterson, Crystalline Gold in Soil and the Problem of Supergene Nugget Formation: Freezing and Exclusion as Genetic Mechanisms. Precambrian Research, 1985, 30, 321-335 

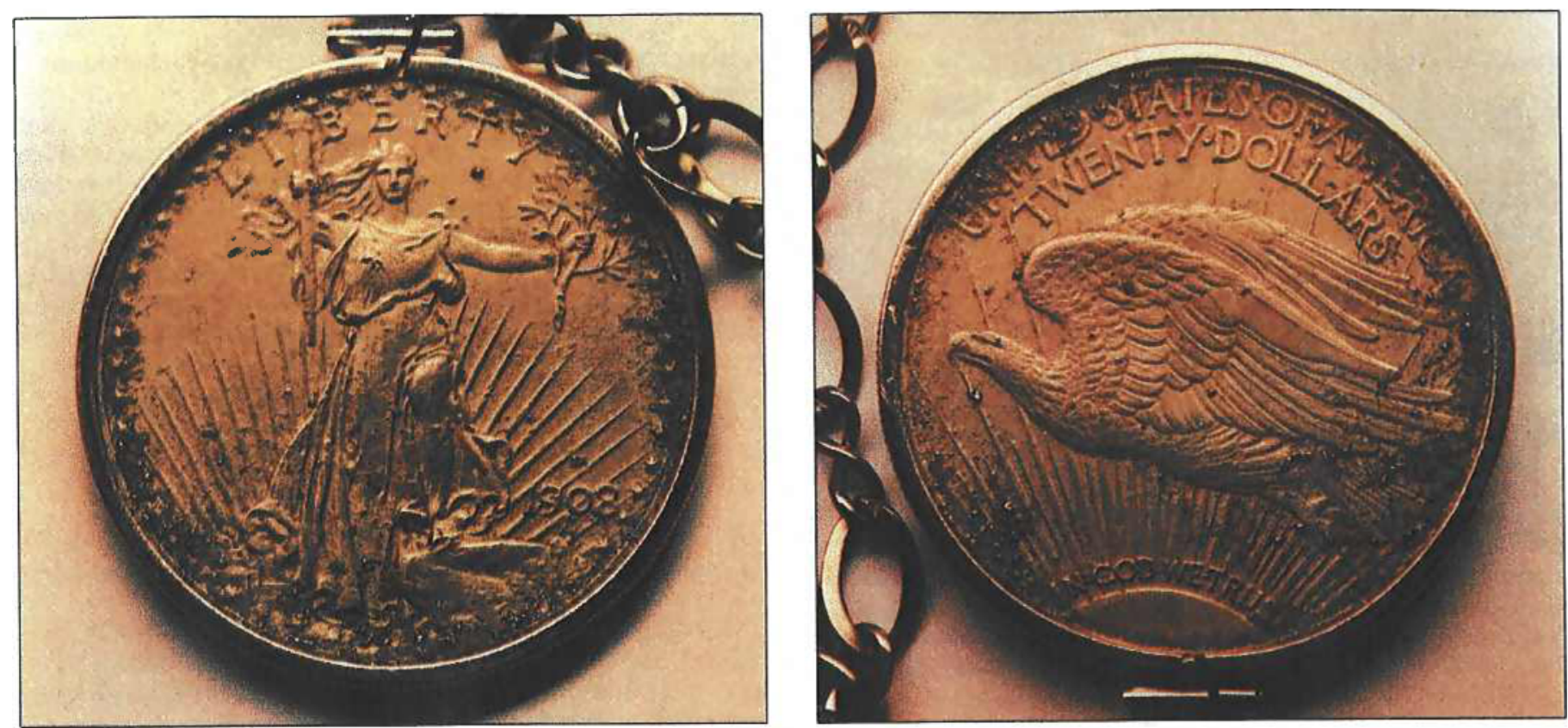

The Parker Gold Piece (left: obverse; right: reverse) showing adhering gold particles predominantly concentrated along the perimeter of the coin. Actual diameter is $3.4 \mathrm{~cm}$.

Photomicrographs of the gold particles adhering to the Parker Gold Piece. Enlargement $x$ 30. (Photos courtesy of L. Lueck)
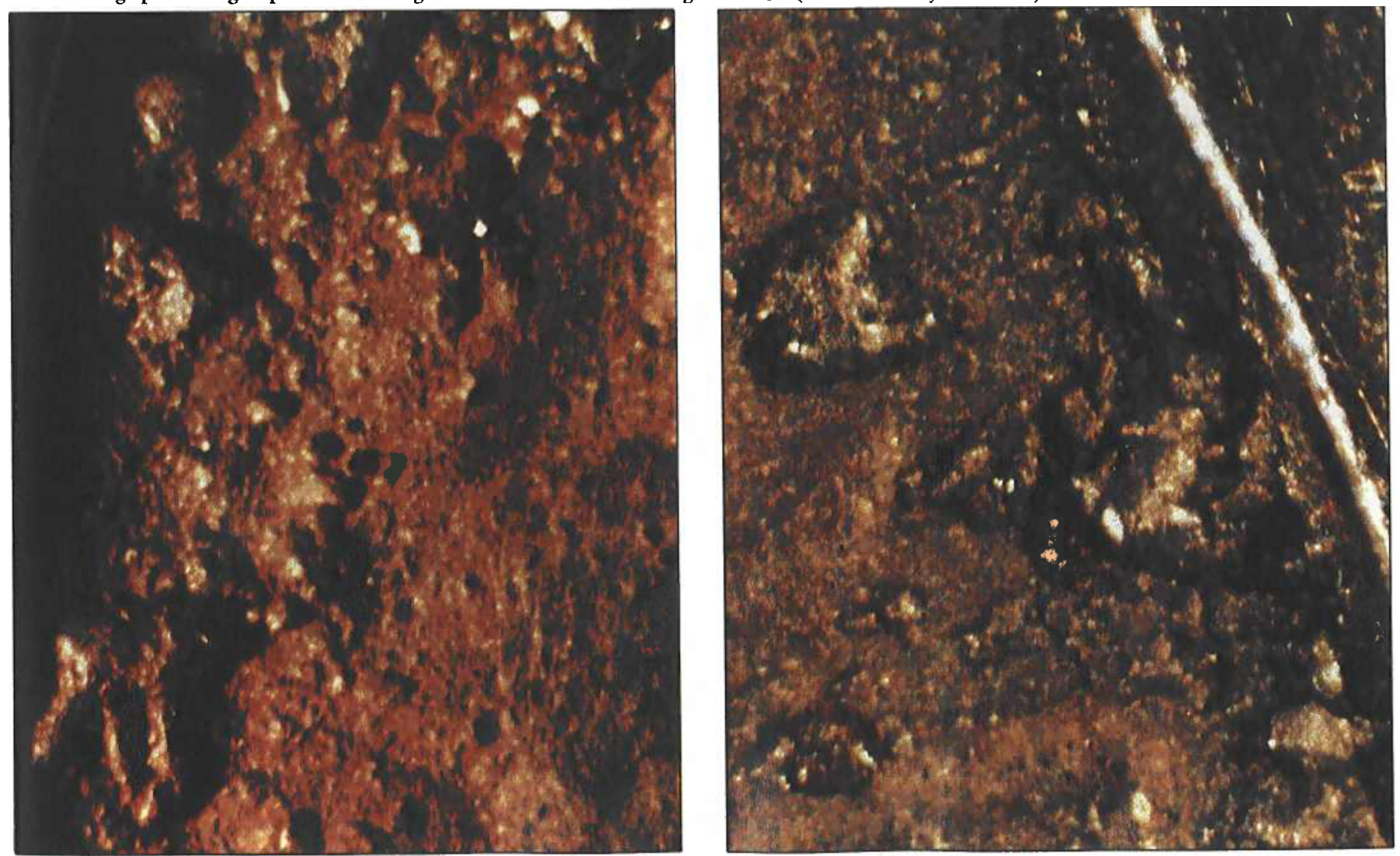

Gold Bull., 1986, 19, (3) 